\title{
The (Nonlinear) relationship between Exchange rate uncertainty and trade. An investigation of US trade figure in the Group of seven
}

\author{
${ }^{1}$ Sikandar Mirza, ${ }^{2}$ Maam Maria, ${ }^{3}$ Aysha Ahter, ${ }^{4}$ Muzna
}

\begin{abstract}
In this paper Bilateral models formulizing monthly growth of US imports and exports are hired to explore the prospective of nonlinear relationships between exchange rate uncertainties and trade growth.

Parametric linear and nonlinear along with semi parametric time series models are in terms of fitting and ex stake estimating. The whole impact on exchange rate differences in trade growth is found to be weak. In periods of large exchange rate differences, trade growth gain from conditioning on instability. Experiential effects maintenance the view that the relationship of interest might be nonlinear and beside, lacks similarity across countries and imports vs. exports. JEL no. C14, C22, F31, F41
\end{abstract}

Keywords: exchange rate instability; international trade; ARCH; Group of seven forecasting.

\section{Introduction:}

Since the end of the Bretton Woods era, there is a large body of theoretical and experimental pure literature historical has emerged to change the rate of the process international Trade flows. The Seminal argument, put forth by Ethier (1973), to make it the agent on the issue often uncertain. Then, the desire may hate risk under exporter (if possible) on the future market, the risk rate to apply on the fence because the power to reduce the number reduce the number of dealer additional cost face flex. Policy effects are felt quickly, and there was a perceived excellence rate to replace the outgoing babble system as, e.g., to move a specific antitissue, foreign body is weighted to be on the domestic economy of distrust by post to stop the inflammatory damage improvement against creating universal individuality. In fact, a very important debate about wealth of European cash when building system or wealth of European Union of about was cash is both a threat and thus less power or will to change the rate to get courage under the trade.

\section{Definition:}

The price of one country's currency expressed in another country's currency. In other words, the rate at which one currency can be exchanged for another. For example, the higher the exchange rate for one euro in terms of one yen, the lower the relative value of the yen.

\section{Effects of exchange rate:}

Foreign currency exchange rates can influence aggregate demand in either direction. As the price level drops, interest rates falls, domestic investment in foreign countries increases, the real exchange rate depreciates, net exports increase, and aggregate demand increases.

A lower-value currency will mean fewer imports and more exports. The change in net exports will mean that the quantity of real GDP produced is higher.

More general economic factors that explain fluctuating exchange rates include:

Economic policy, disseminated by government agencies and central banks, and economic conditions, generally revealed through economic reports and other economic indicators.

\section{Literature:}

Exchange rate affects the trade exchange rate uncertainty put adverse effect on trade or some time work as stimulus for the trade. Sometime uncertainty in exchange rate leaves positive effect in the exchange rate when exporter revenue is convex in exchange rate and viaene and devres.exchange rate also effect in both directioneven in perfect heading.

In uncertainty situation of exchange rate effect of it unclear and trade at the theoretical level now it become an empirical issue to uncover if trade is restricted in volatility exchange rate in empirical view there is no consensus available empirical literature on this issue is conflicting .some researcher find significant adverse effect on trade and many researcher also not conclude any significant relation between exchange rate volatility and trade.

Recent studies based on asmall group assembled to investigation or decide on a matter estimate techniques in general and the called solemnity model in particular extent, empirical established negative relation between trade and exchange rate volatility. Typically estimate with low frequency study (yearly, quarterly) 
gravity models have become a major tools expose a motivating effect of monetary operations on the level of trade. We evaluate the alive relationship between trade and exchange rate ambiguity at higher frequencies monthly say time series approaches are still instructive for many practical issues.

For example, short run forecasting parametric literature has benefited for major standard used for comparison in econometrics. Introduction of cointegration and autoregressive conditionery series process, two promising of parametric work have not been followed all available parametric studies focus a thing regarded as more important than other on linear relationship between the variables of interest. On the other hand fundamental true crash of exchange rate uncertainty on trade exists nonlinear.

Therefore following the first promising way this parametric study provides a detailed evaluate of linear vs. nonlinear requirement of mutual models explain as import and export in the group of seven. There show no challenge in parametric literature to employ recommend models for present forecasting. One reason not to think about forecasting assets exist that most time series models describing trade pattern fail to pass simple regression analytic for the huge majority of these models estimated mistake terms shows important association. Which is infrequently accounted for and is likely to deterioral performance in this paper, substitute models related to trade and exchange rate uncertainty are match up in terms of instructive power and y means respect to their correctness in present forecasting?

The leftover of the paper is arranged as follow the next section provides as ordinary approach to enumerate the relationship between trade and exchange rate ambiguity a linear regression model in section. Parametric and semi parametric additional of the linear model are encourage and applied the struggle approach to modeling trade evaluate are match up in teams of present forecasting performance.

\section{Conclusion}

R SQURE value .371 shows that independent variable explains the $37 \%$ of dependent variable .this value also shows that modal fitness is very weak.

In table of ANOVAs significant value of F static is .393 here this hypothesis is

H0: There is no linear relationship

HA: There is linear relationship

Value of $\mathrm{p} .393$ is greater than the alpha value 0.05 which shows that there is no linear relationship between independent variable and dependent variable

In table of coefficient value of constant is 103,892 and value of GDP,IMPORT EXPORT IS --.269,-.413,.382 which shows that GDP and import negatively affect an exchange rate but $p$ value of DGP and import .451,.264 shows that effect is insignificant can export positively affect the exchange rate with value of .382 .but effect insignificant

[1]. Anderton, R., and R Skudelny (2001).

[2]. Exchange Rate Volatility and Euro Area Imports. European Central Bank Working Paper Series 64.

[3]. Frankfurt/Main.Arize, A. C. (1996). Real Exchange Rate Volatility and Trade Flows: The Expe- rience of Eight European Economies. International Review of Economics and Finance 5 (2): 187-205. Arize, A. C. (1998). The Long-Run Relationship between Import Flows and Real Exchange Rate Volatility: The Experience of Eight European Economies. International Review of Economics and Finance 1 (4): 417-435. Artus, J. R. (1983).

[4]. Toward a More Orderly Exchange Rate System. Finance and Development 20 (1): 10-13. Asseery, A., and D. A. Peel (1991).The Effects of Exchange Rate Volatility on Exports. Economics Letters 37 (2): 173-177.

[5]. 680 Review of World Economics 2003, Vol. 139 (4) Bailey, M. J., G. S. Tavlas, and M. Ulan (1986). Exchange Rate Variability and Trade Performance: Evidence for the Big Seven Industrial Countries. WeltwirtschaftlichesArchiv 122 (3): 466-477. Bailey, M. J., G. S. Tavlas, and M. Ulan (1987). The Impact of Exchange Rate Volatility on Export Growth: Some Theoretical Considerations and Empirical Results. Journal of Policy Modeling 9 (1): 225-243. Bini-Smaghi, L. (1991). Exchange Rate Variability and Trade: Why Is It So Dif- ficult to Find Any Relationship. Applied Economics 23 (5): 927-936. Bollerslev, T. (1986).Generalized Autoregressive Conditional Heteroskedastic- ity. Journal of Econometrics 31 (3): 307-327. Bollerslev, T, and J. M. Wooldridge (1992). Quasi Maximum Likelihood Esti- mation and Inference in Dynamic Models With Time Varying Covariances. Econometric Reviews 11 (2): 143-172. Breusch, T. S. (1978). Testing for Autocorrelation in Dynamic Linear Models. Australian Economic Papers 17 (31): 334-355. Brodsky, D. A. (1984).Fixed versus Flexible Exchange Rates and the Meas- urement of Exchange Rate Instability. Journal of International Economics 16 (3/4): 295-306. Commission of the European Communities (1990). One Market, One Money. European Economy 44. De Grauwe, P. (1988). Exchange Rate Variability and the Slowdown in Growth of International Trade. IMF Staff Papers 35 (1): 63-84. De Grauwe, P., and D. Bellefroid (1986).

[6]. Long Run Exchange Rate Variability and International Trade.In S. Arndt and J. D. Richardson (eds.), Real Fi- nancial Linkages among Open Economies. Cambridge, Mass.: MIT Press. De Grauwe, P., and F. Skudelny (2000). The Impact of EMU on Trade Flows.WeltwirtschaftlichesArchiv 136 (3): 381-402. DeH'Ariccia, G. (1998). Exchange Rate Fluctuations and Trode Flows: Evidence from the European Union. IMF Working Paper 98/107.Demers, M. (1991). 